\title{
The prediction of tsunami travel time to Mataram City Indonesia based on North Lombok earthquake as the initial condition
}

\author{
Eko Pradjoko ${ }^{1, *}$, Lukita Wardani $^{1}$, Hartana $^{1}$, Heri Sulistiyono ${ }^{1}$, Syamsidik $^{2}$ \\ ${ }^{1}$ Study Center for Disaster Risk Management, Faculty of Engineering, University of Mataram, Jl. Majapahit no.62, Mataram, \\ Indonesia \\ ${ }^{2}$ Tsunami and Disaster Mitigation Research Center (TDMRC), Syiah Kuala University, Jl. Prof. Dr. Ibrahim Hasan, Gampong \\ Pie, Banda Aceh, Indonesia
}

\begin{abstract}
The past earthquake records in North Lombok show the high level of earthquake hazard in this area. The maximum magnitude of the earthquake was $6.4 \mathrm{Mw}$ on May 30th, 1979. But, there were no tsunami events records due to those earthquakes. Nevertheless, this area is very close to Mataram City (province capital city) and tourism area. Therefore, the assessment of tsunami hazard is very important. The tsunami simulation was conducted by using COMCOT Model, which is based on the North Lombok Earthquake as the initial condition. The simulation result shows the prediction of tsunami travel time is about $18 \sim 20$ minutes from the source location to Mataram City. The height of the tsunami wave is $0.13 \sim 0.20$ meters due to the earthquake magnitude is about $6 \mathrm{Mw}$.
\end{abstract}

\section{Introduction}

The Lombok Island is located exactly on the east side of Bali Island. This island and Sumbawa Island are part of West Nusa Tenggara (WNT) Province, Indonesia. The position of WNT Province is near to the subducting zone in the Hindia Ocean on the south. Therefore, this area has earthquakes and even a tsunami disaster experiences. According to the Indonesia Disaster Prevention National Agency (BNPB), the WNT Province is classified as moderate to the high level of earthquake disaster risk [1]. Reference [2] also shows the Peak Ground Acceleration (PGA) value of WNT Province was about $0.05 \mathrm{~g} \sim 0.5 \mathrm{~g}$.

The big earthquake had occurred at Lombok Island on May 30th, 1979. The earthquake magnitude was 6.4 $\mathrm{Mw}$ and the epicenter was located in the Lombok Straits (see Fig. 2 and Table 1). It was reported 37 people died .and hundreds of houses were broken. The recent devastating earthquake was on June 22th, 2013. The magnitude is $5.7 \mathrm{Mw}$ but the epicenter was nearer the island. There was no human died but about 50 people wounded and a thousand houses were damaged as reported by BNPB [3].

Earthquakes have occurred in the North Lombok Area with the epicenter in Lombok Straits or the Bali Sea. However, there is no any report about tsunami event due to those earthquakes. The initial presumption was the earthquake magnitude is still quite low to generate a tsunami. Nevertheless, the epicenter location was very close to Mataram City (the capital of WNT Province), which have densely populated. The total population of
Mataram City has recorded 459,314 persons in 2016 and the population growth was about $2.02 \%$ [4]. The average population density of Mataram City was 7,493 persons per square kilometer. The density growth is $8.8 \%$ since last five years. Therefore, the assessment of tsunami hazards is important to conduct in this area.

This research is the initial assessment of tsunami hazards due to the North Lombok earthquake. The past earthquake record will be analyzed and the tsunami simulation will be conducted. The simulation used COMCOT Model, which is a numerical method from Professor Liu [5]. The research objective is to get the prediction of the tsunami travel time and other characteristics, such as: run up height and inundation depth.

\section{Methodology}

The earthquake data and fault mechanism were taken from USGS [6]. The rupture parameters were calculated using Wells \& Coppersmith's method [7]. The Okada's method [8] was applied to compute the sea surface displacement, which is based on rupture parameters.

The numerical simulation of tsunami propagation was performed by using the Cornell Multi-grid Coupled Tsunami Model (COMCOT), which is developed by Professor Phillip L-F Liu from Cornell University [5]. The COMCOT is an open source program and applies the long-wave equation or shallow water equation for simulating the propagation of tsunami from the source

\footnotetext{
Corresponding author: ekopradjoko@unram.ac.id
} 
until coastal area. The model has been used to investigate several historical tsunami events, such as the 1960 Chilean tsunami, the 1992 Flores tsunami [9], and more recently the 2004 Indian Ocean tsunami [10].

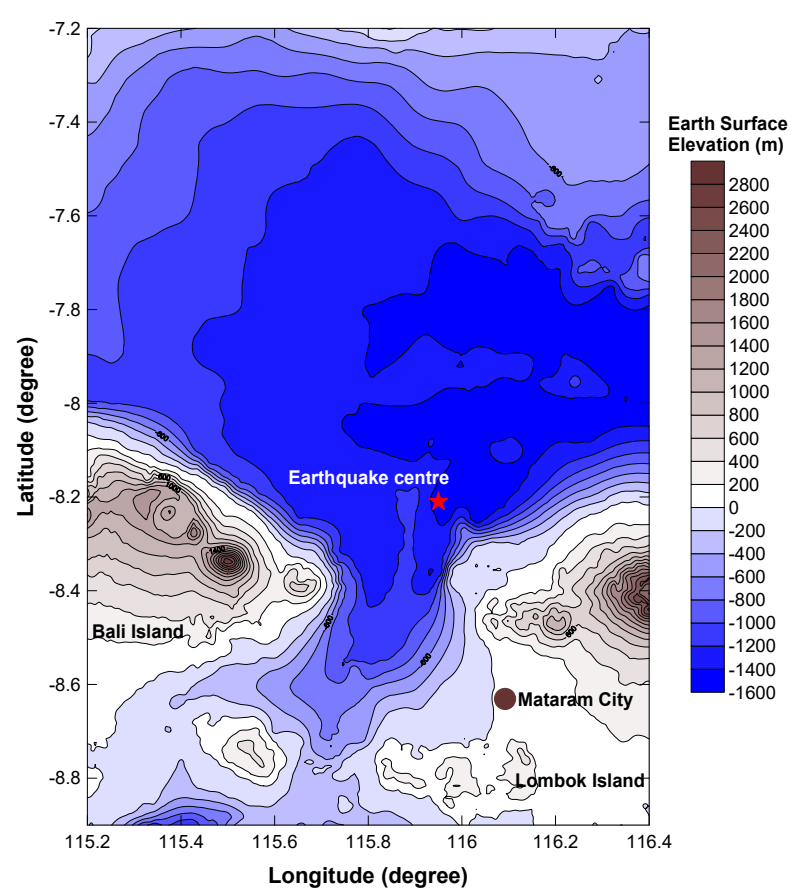

Fig. 1. The bathymetry of study area.

COMCOT uses a modified leap-frog finite difference scheme to solve shallow water equations in a staggered finite difference nested grid system. The shallow water

equations in a Cartesian coordinate system are expressed as:

$$
\begin{gathered}
\frac{\partial \eta}{\partial t}+\left\{\frac{\partial P}{\partial x}+\frac{\partial Q}{\partial y}\right\}=0 \\
\frac{\partial P}{\partial t}+\frac{\partial}{\partial x}\left\{\frac{P^{2}}{H}\right\}+\frac{\partial}{\partial y}\left\{\frac{P Q}{H}\right\}+g H \frac{\partial \eta}{\partial x}+F_{x}-f Q=0 \\
\frac{\partial Q}{\partial t}+\frac{\partial}{\partial x}\left\{\frac{P Q}{H}\right\}+\frac{\partial}{\partial y}\left\{\frac{Q^{2}}{H}\right\}+g H \frac{\partial \eta}{\partial y}+F_{y}+f P=0
\end{gathered}
$$

Where :

$\eta=$ water surface elevation (m)

$\mathrm{P}=$ volume flux in $\mathrm{x}$ direction $(\mathrm{m} 2 / \mathrm{sec})$

$\mathrm{Q}=$ volume flux in $\mathrm{y}$ direction $(\mathrm{m} 2 / \mathrm{sec})$

$\mathrm{H}=$ total water depth $(\eta+\mathrm{h}$, in meter $)$

$\mathrm{h}=$ water depth $(\mathrm{m})$

$\mathrm{g}=$ gravitational acceleration $(\mathrm{m} / \mathrm{sec} 2)$

$\mathrm{F}_{\mathrm{x}}=$ bottom friction in $\mathrm{x}$ direction

$\mathrm{F}_{\mathrm{y}}=$ bottom friction in $\mathrm{y}$ direction

$\mathrm{f}=$ Coriolis force coefficient

The bathymetry data was taken from the General Bathymetric Chart of the Oceans (GEBCO) [11]. The data were used as a numerical grid mesh covering the area from $7.2^{\circ}$ to $8.9^{\circ} \mathrm{S}$ latitude and $115.2^{\circ}$ to $116.4^{\circ} \mathrm{E}$ longitude. The mesh size is $30 \mathrm{secs}$ (about $928 \mathrm{~m}$ ) in both directions. The Fig. 1. shows the condition of bathymetry and location of Mataram City. It shows the Lombok Straits is very deep, i.e. about $-800 \sim-1,000 \mathrm{~m}$, from the Bali Sea on north until the Hindia Ocean on the south. The Mataram City is located on the coast in the west side of Lombok Island and facing the Lombok Strait

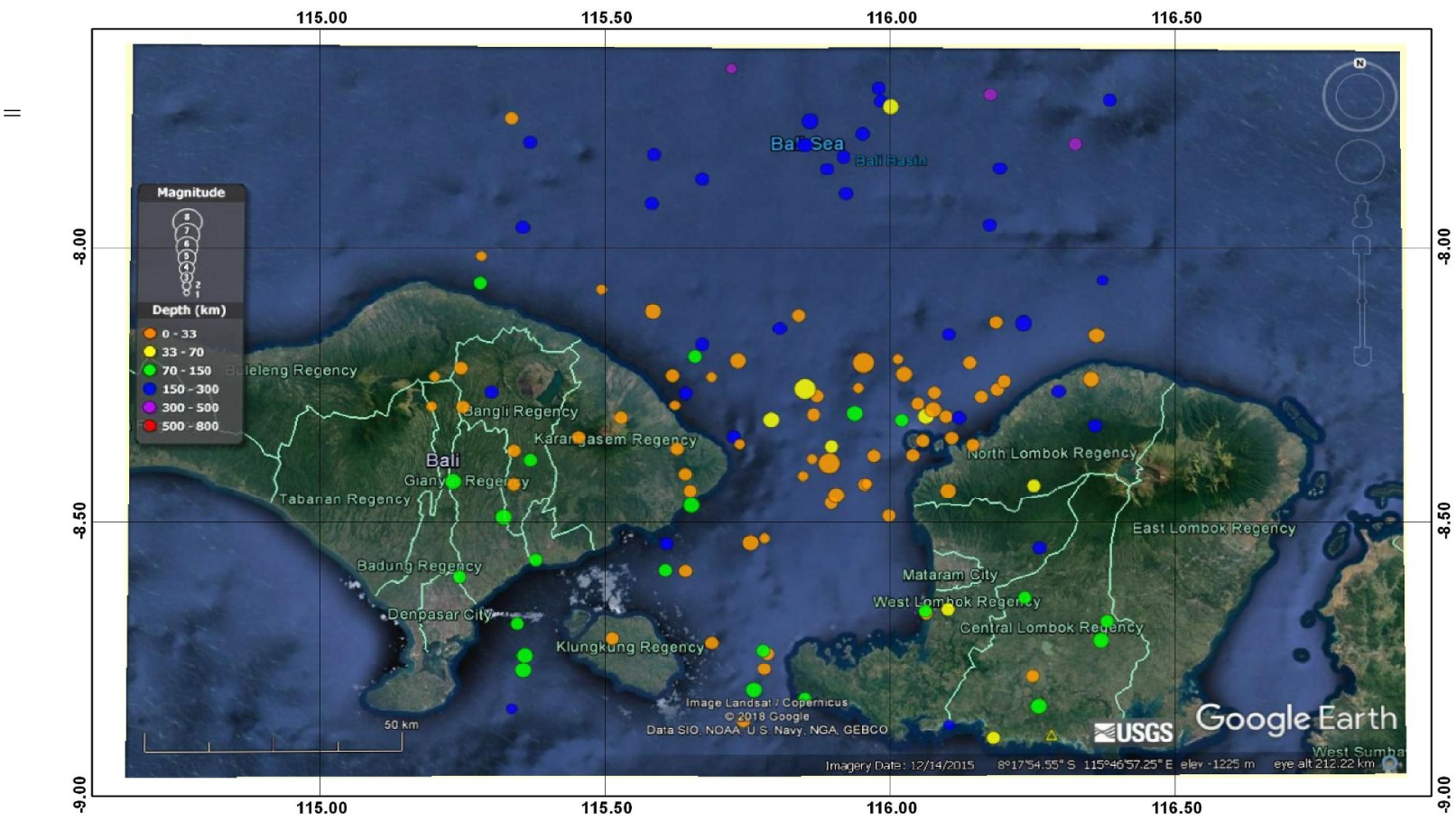

Fig. 2. The records of earthquake events between 1960 - 2017. 


\section{Results and discussion}

Based on USGS records [6], the earthquake records from 1960 until 2017 in this area show 136 numbers of events. It is 2 earthquake events per year on average. There are $107(79 \%)$ events, which occur in below seabed as shown in Fig. 2. Most of them are located in the Lombok Straits, north-west of Lombok Island. One requirement of a tsunami event is the sea location of the earthquake.

The other requirements of tsunami event are the earthquake magnitude must bigger than $6.0 \mathrm{Mw}$ and the epicenter depth is lower than $33 \mathrm{~km}$ (shallow earthquake). Fig. 3. shows that the earthquake magnitude bigger than $6.0 \mathrm{Mw}$ are only six (4\%) events. However, there are $60(44 \%)$ events, which have an epicenter depth lower than $33 \mathrm{~km}$. The earthquake hazard is mostly influenced by a shallow earthquake type as explained in [2].
The data show that this area has the frequent earthquake experiences. Based on the characteristics, most of the earthquake events also meet with some requirement of tsunami event, i.e. sea location and shallow epicenter depth. However, there are only 6 events that have a magnitude bigger than $6.0 \mathrm{Mw}$, which is part of the tsunami requirement. Table 1 show those four of six biggest earthquakes data, which had happened in Lombok Straits or the Bali Sea.

Table 1. shows the focal mechanism of four biggest earthquakes, which are the type is almost equal, i.e. reverse type. Based on the focal mechanism, all four earthquakes have met the criteria of the tsunami event. However, the tsunami is never reported in these events. The possible reason is the tsunami absolutely does not occur or occur with small magnitude.

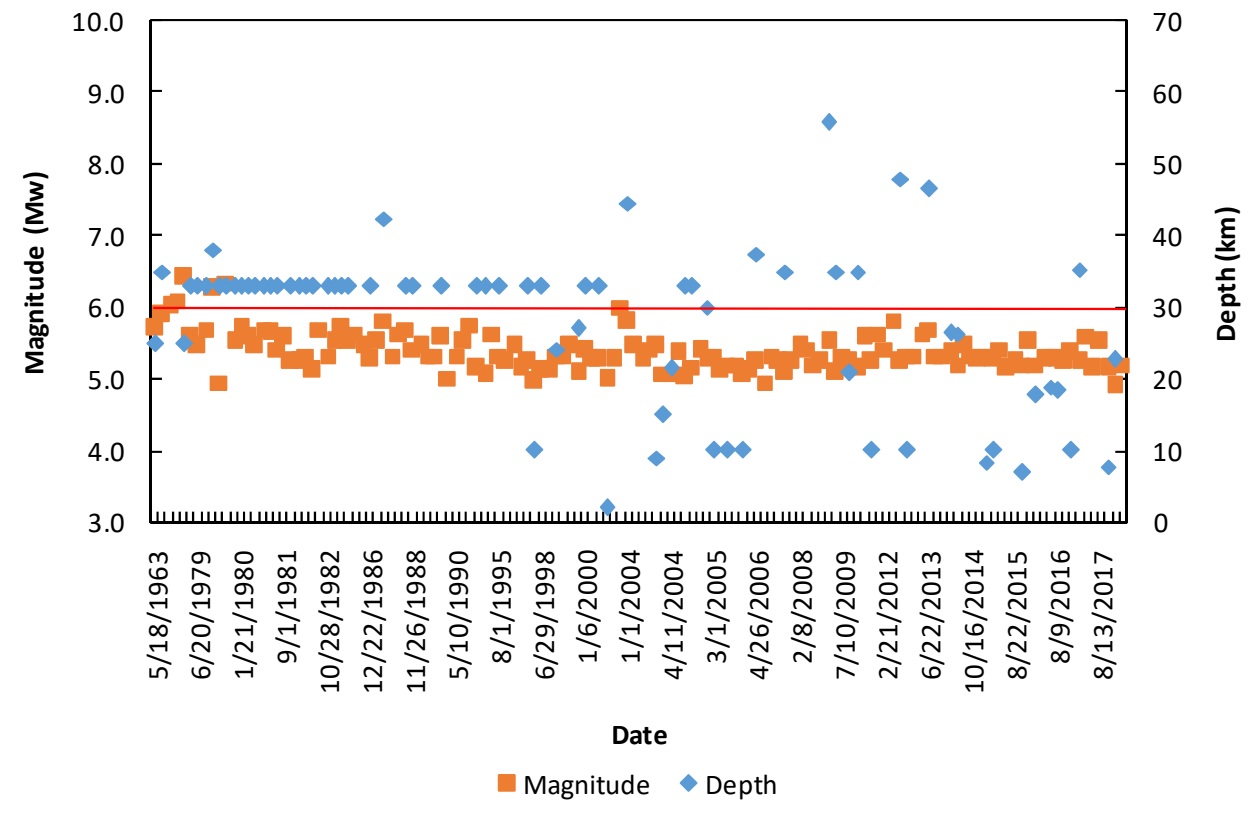

Fig. 3. The location, magnitude and epicenter depth of earthquake events from $1960 \sim 2017$.

Table 1. The characteristics of four biggest earthquakes in Lombok Straits.

\begin{tabular}{|c|c|c|c|c|c|}
\hline $\begin{array}{c}\text { Date and Time } \\
\text { (UTC) }\end{array}$ & $\begin{array}{c}\text { Latitude } \\
(\mathbf{0})\end{array}$ & $\begin{array}{c}\text { Longitude } \\
(\mathbf{(})\end{array}$ & $\begin{array}{c}\text { Magnitude } \\
\text { (Mw) }\end{array}$ & $\begin{array}{c}\text { Epicenter Depth } \\
(\mathbf{k m})\end{array}$ & Focal Mechanism \\
\hline 1979-05-21 16:31:05 & -8.30 & 115.93 & 6.1 & 76 & \\
\hline $1979-05-3009: 38: 52$ & -8.21 & 115.95 & 6.4 & 25 & \\
\hline $1979-10-2001: 41: 10$ & -8.25 & 115.85 & 6.3 & 38 & \\
\hline $1979-12-1719: 58: 23$ & -8.39 & 115.89 & 6.3 & & \\
\hline
\end{tabular}



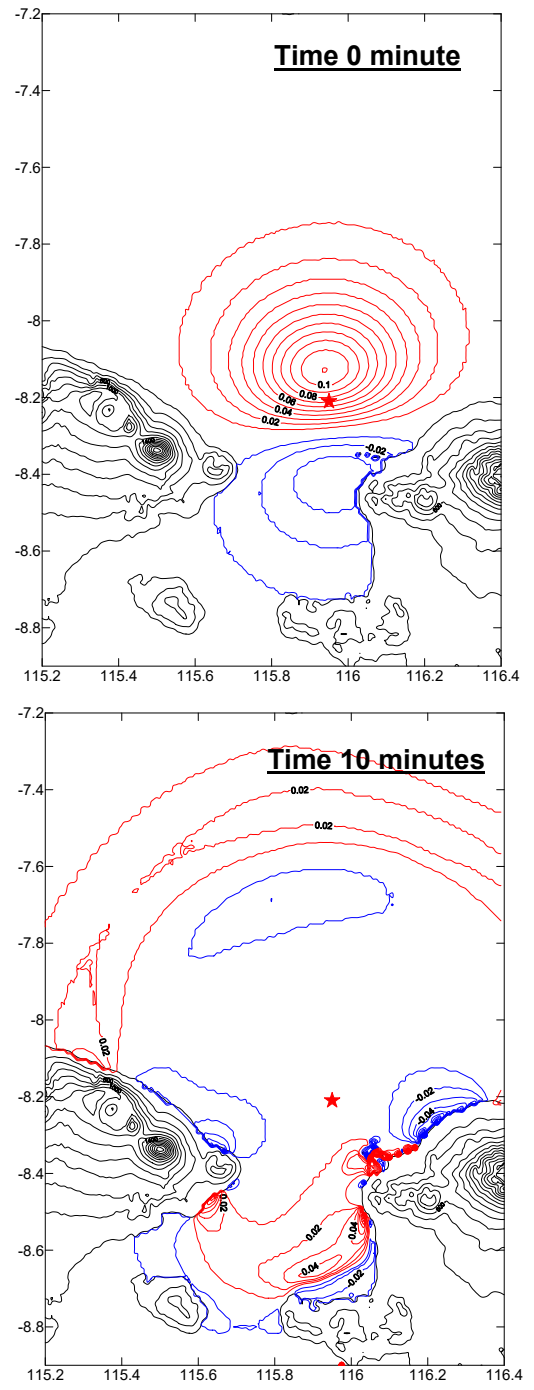

Fig. 4. The simulation of tsunami propagation in $0,5,10$, and 15 minutes.

Therefore, the numerical simulation was performed to examine the tsunami occurrence of those earthquake events. Among the four biggest earthquakes in Table 1, the May 30th, 1979 event was chosen to simulate due to having the biggest magnitude $(6.4 \mathrm{Mw})$ and shallower depth $(25 \mathrm{~km})$. According to the Wells \& Coppersmith's method [7], the rupture or fault parameters of that earthquake event are presented in Table 2. The parameters above become data entry of fault parameters in COMCOT model. The mesh size $(\mathrm{dx})$ is 30 secs (about $928 \mathrm{~m}$ ) in both directions. The time step (sec) is 0.12 seconds taking into account the stability condition.

Table 2. The rupture fault parameters.

\begin{tabular}{|l|c|c|}
\hline \multicolumn{1}{|c|}{ Parameter } & Dimension & Unit \\
\hline Length & 19.59 & $\mathrm{~km}$ \\
\hline Width & 10.33 & $\mathrm{~km}$ \\
\hline Depth & 25 & $\mathrm{~km}$ \\
\hline Dislocation & 2.5 & $\mathrm{~m}$ \\
\hline Strike angle & 265 & degree \\
\hline Dip angle & 72 & degree \\
\hline Slip or Rake angle & 92 & degree \\
\hline
\end{tabular}
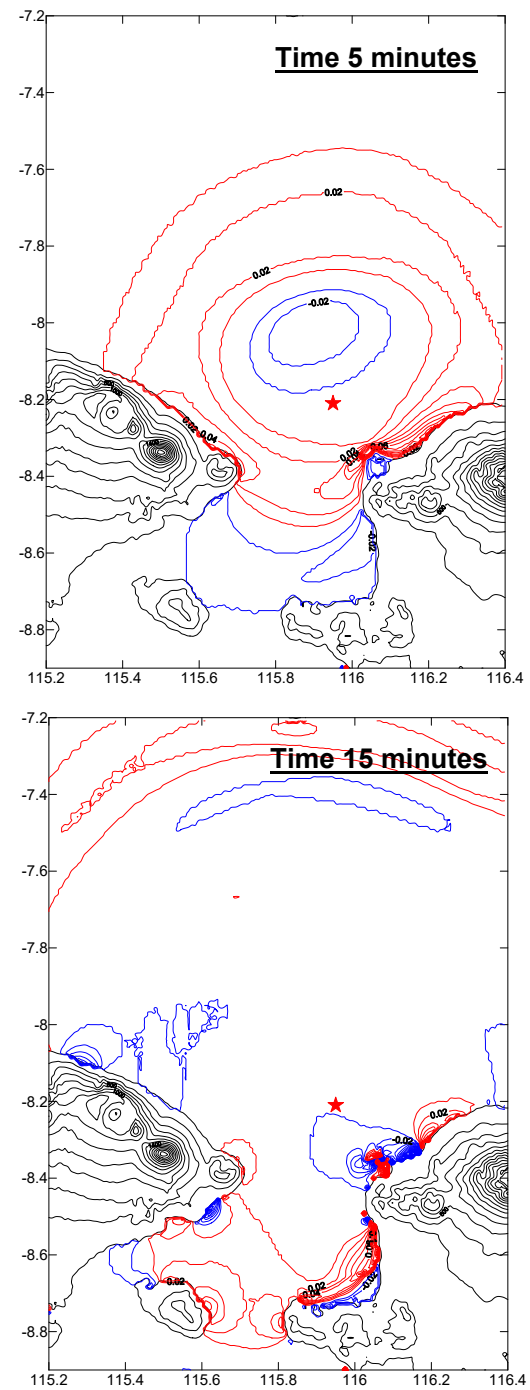

Fig. 4. shows the simulation of tsunami wave propagation after $0,5,10$ and 15 minutes. The red line shows the rising of the water surface and the blue line shows the lowering of the water surface. Those pictures clearly show that the tsunami wave needs more than 15 minutes to arrive in the Mataram City from the source location. The Fig. 5 shows more clearly that the tsunami waves arrive in 20 minutes to the Mataram City. Along the Lombok Straits, the waves move fast due to the big depth of straits. In front of Mataram City, the waves move slower (from $10 \sim 20$ minutes) due to the shallow depth in that area.

However, the simulation also shows that the wave height is low. At 0 minute, the initial wave height is only 0.13 meter. Along the propagation time, the highest wave is only 0.20 meter. It is caused by the earthquake magnitude characteristics. The magnitude is relatively low $(6.4 \mathrm{Mw})$ that make the rupture parameters are too small to make a high wave. The earthquake epicenter location is also relatively not far from the mainland. This short distance makes the wave does not have enough space and time to become higher due to the shoaling effect. Therefore, the tsunami cannot run up or inundate the higher land. 


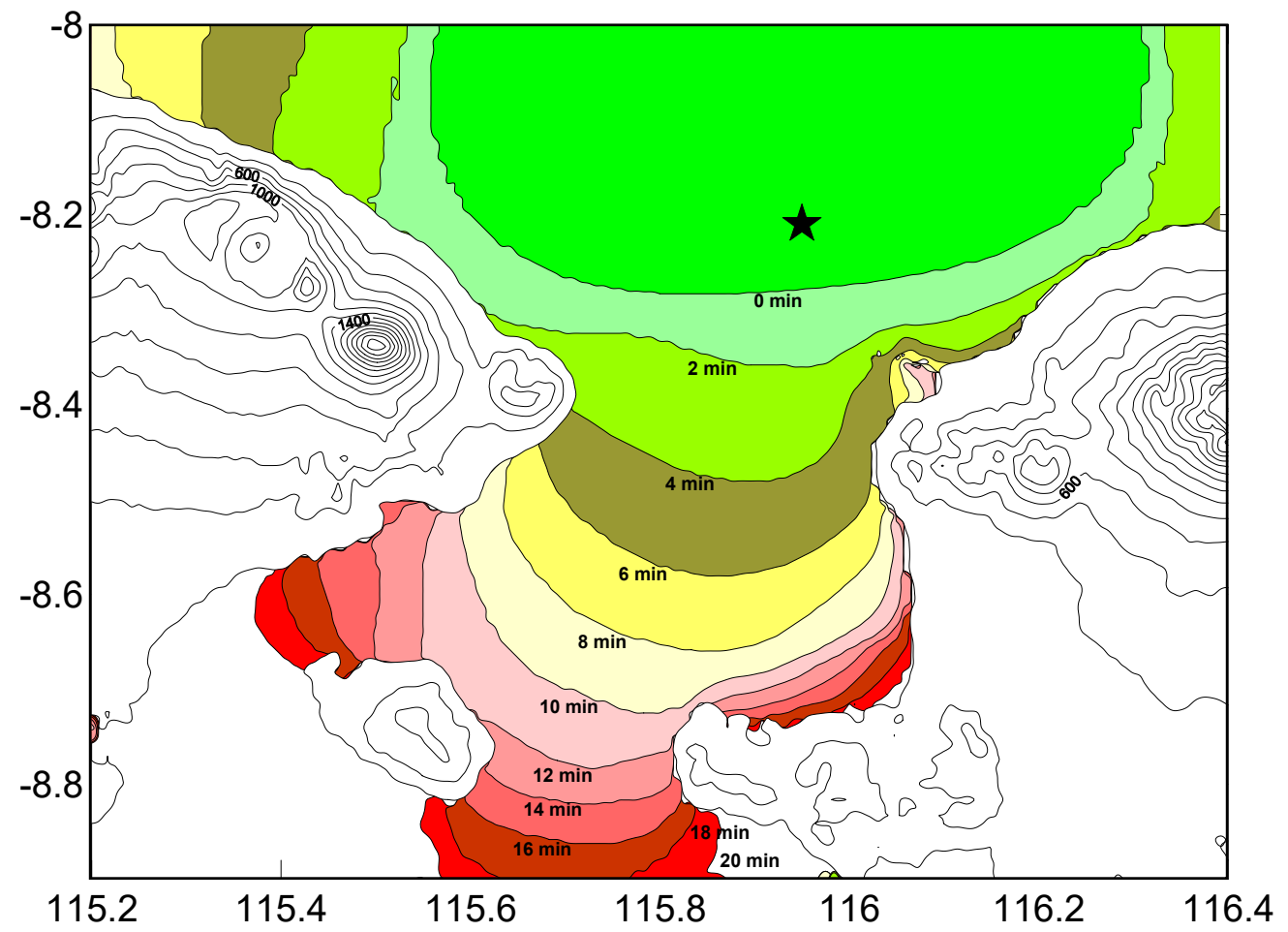

Fig. 5. The tsunami travel time.

\section{Conclusions}

The earthquake record analyses of North Lombok area has been performed. The results show the high level of earthquake hazards in this area. Even there is no tsunami report; the numerical tsunami simulation was conducted to assess the tsunami hazards based on the North Lombok Earthquake scenario. It is predicted that the tsunami travel time is $18 \sim 20$ minutes until arriving in Mataram City. The tsunami wave height is only 0.13 0.20 meter along that time. This height is very small and corresponds to the small earthquake magnitude. Consider the tsunami impact on Mataram City and surrounding area, the simulation will perform with the bigger earthquake magnitude scenario for the next study.

We would like to thank the Partnership Enhanced Engagement in Research (PEER) Cycle 5 promoted by United States Agencies for International Development (USAID) and the National Academies of Sciences, Engineering, and Medicine (NAS), under Sponsor Grant Award Number: AID-OAA-A11-00012 and sub-Grant Number PGA-2000007546 with the title of the research project 5-395: Incorporating climate change induced sea level rise information into coastal cities' preparedness toward coastal hazards for supporting this study.

\section{References}

1. M.R. Amri, G. Yulianti, R. Yunus, S. Wiguna, A.W. Adi, A.N. Ichwana, R.E. Randongkir, R.T. Septian, Indonesia Disaster Risk (BNPB, in Bahasa, 2016)

2. J. Nugraha, G. Pasau, B. Sunardi, S. Widiyantoro, JMG, 15, 1, 1-11 (2014)
3. T. Budiarto, The Earthquake Disaster Emergency Response in North Lombok District (BNPB, 2013)

4. Mataram City in Data (BPS Mataram, 2017)

5. P.L-F. Liu, S.B. Woo, Y.S. Cho, Computer programs for tsunami propagation and inundation (Cornell University, 1998)

6. (2018) The Earthquake Hazards Program - USGS website.[Online].Available:https://earthquake.usgs.g ov/earthquakes/

7. S. L. Kramer, Geotechnical Earthquake Engineering (Prentice Hall, 1996)

8. Y. Okada, BSSA, 75, 4, 1135-1154 (1985)

9. P.L-F. Liu, Y.S. Cho, S.B. Yoon, S.N. Seo, Recent development in tsunami research (Kluwer Academic Publishers, 1994)

10. X. Wang, P.L-F. Liu, JET, 1, 3, 273-297 (2007)

11. (2018) The General Bathymetric Charts of the Oceans - GEBCO website. [Online]. Available: https://www.gebco.net/ 